
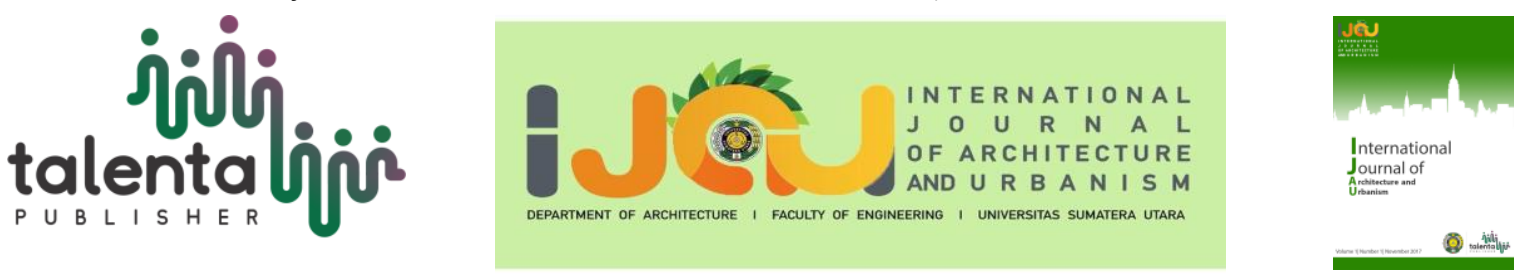

\title{
Characteristics of Vernacular Architecture Malay Deli Traditional House Based on Technical Aspects of Building Structure
}

\author{
Novrial $^{1 *}$, Nila Rahmaini Siregar ${ }^{1}$ \\ ${ }^{I}$ Architecture Department, Faculty of Engineering, Universitas Sumatera Utara, Medan, Indonesia
}

\begin{abstract}
Local wisdom in an architectural context is part of cultural heritage, passed down from generation to the next generation and gone through a long process of gaining community recognition as a reflection of the region's culture, also known as vernacular architecture. Vernacular architecture can be found in almost every region, as is the city of Medan. Medan city is famous for its culture, especially its Malay culture, formed by the Sultan of Deli's influence so that Malay Deli emerged. In its formation, aspects of the creation of vernacular architecture also influenced the development of Malay Deli, mainly traditional houses. These traditional houses is visible from one of its forming aspects in the form of technical aspects such as building structure systems. This study discusses the characteristic of system structure in the Malay Deli traditional house and aims to identify and examine these problems. This study adopted a qualitative descriptive method approach to collect and analyze data so that the results obtained in the form of technical aspects of the structure of vernacular building structures from traditional Malay. This study's findings are a reference source for traditional Malay houses' vernacular architecture, specifically Malay deli or design considerations.
\end{abstract}

Keyword: characteristic, structure, traditional, technical, vernacular

Received 12 May 2021|Revised15 July 2021 | Accepted 25 August 2021

\section{Introduction}

Local wisdom is a cultural product that is practically the root of a cultural value believed by the community as a result of consideration of the surrounding environment [1] [2], and is used to create sustainable life, especially in the field of architecture.

In architecture, local wisdom is the solution that leads to building management policies and ecological problems [2]. As a context of local wisdom, architecture also has the same connection with vernacular architecture, both of which are born from the people's aspirations and refer to the real problems of the environment, climate, and others [3].

\footnotetext{
*Corresponding author at:Department of Architecture, Faculty of Engineering, Universitas Sumatera Utara, Medan 20155, Indonesia

E-mail address: novrial@usu.ac.id
} 
Vernacular architecture is known to be the development of folk architecture in the form of traditional houses sourced from local communities and open to developing its transformation [4]. This change is based on aspects of its formation, including technical elements in the form of the design process, structure, and forming material [5].

Traditional houses in each region have their uniqueness. It reflects its characteristics, such as one of the traditional houses in Medan, known as the Malay Deli. This traditional house is a Malay house influenced by the Sultan Deli [6]. In the construction process, the conventional Malay Deli house has changed due to adapting to the surrounding environment to be sustainable, one of which is from its technical aspects [7]. The technical point is the system used in constructing buildings in the design processes, structures, and materials of its constituents [8].

This paper discusses the identification and studies. Their characteristics of the vernacular architecture in the traditional Malay Deli house are reviewed from the building structure system's technical aspects.

\section{Literature Review}

\subsection{Vernacular Architecture}

Vernacular architecture is a reflection of local traditions that use traditional techniques, especially in forming formations, rules, methods, and materials as a potential environment [9] [10] [11] and is believed to be a sustainable development system in paying attention to its constituent aspects [12].

\subsection{The Forming Aspect of Vernacular Architecture}

The vernacular aspect is a medium for interpreting ideas, problems, situations, or considerations from a particular perspective [13] [14]. The vernacular aspect is divided into elements forming a unity in the form of physical formations and the meaning contained through technical, culturalbased, and influenced by the environment as part of the vernacular architectural concept [14].

\subsection{Technical Aspect}

Technical aspects of vernacular architecture refer to the use of local techniques and materials as well as answers to specific environments that can be seen physically, including structures, construction, and materials that affect the shape of a building [4] [14]. Buildings defined as vernacular architecture are buildings constructed from local materials available directly on-site, which is known as the traditional house of Indonesia [15]. This type of structure can have the connection between poles and beams by connecting the wooden parts as the primary forming material and simple, special tools in the form of machetes, chisels, etc. The connections on a traditional house mainly like to use holes, notch connections, and peg joints. 


\subsection{Structural System}

Understanding the structural system is a means to transfer a load of a building into the ground. In other words, the system structure as in architectural elements that have a mecanism distribution of the weight from the top to the ground (foundation) [16]. The structural system at home simple generally does not differ from the traditional house which consists of three parts of the fundamental elements (Figure 1), namely: the upper structure (substructure), the middle structure (bottom side structure) and lower structure (top side structure) [17].

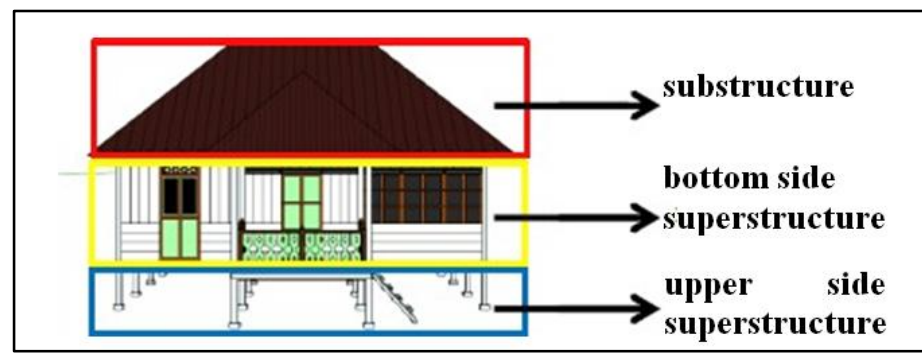

Figure 1 Traditional house structural elements

Components of the structure consists of: building loads in the form of physical forces acting on the building, superstructure that is part of the building frame, the support system lateral, which resists horizontal loads such as wind and earthquakes, masts, or foundation, and geology. Besides, the structural system also consists of elements structures, namely foundations, columns, walls, floors, and roof trusses which can be seen in Table 1 [18] [19].

Table 1 Traditional House Structure System

\begin{tabular}{|c|c|}
\hline Structural Elements & Specification Of Structure Elements \\
\hline substructure & Foundation \\
\hline $\begin{array}{l}\text { bottom side } \\
\text { superstructure }\end{array}$ & $\begin{array}{ll}- & \text { Floor } \\
- & \text { Column } \\
- & \text { Wall } \\
- & \text { Openings (Windows \& Doors) }\end{array}$ \\
\hline superstructure & $\begin{aligned} \text { Palate Roof } \\
-\quad \text { Horses Roof } \\
-\quad \text { Roof Cover }\end{aligned}$ \\
\hline
\end{tabular}

\subsection{Traditional Malay Deli House}

Malay Deli house is an old traditional Malay house under the Deli Sultanate [6]. According to the Sumatra Architecture Exploration (2016), the Malay house's authenticity seen from the shape of the five-sided roof, windows in the form of a stick, pair of wallboards arranged vertically, ornate carvings at the end of the roof.

The space organization at Rumah Melayu Deli divided into three parts between the top, the middle, and the bottom of the building; where is the element the top is the roof (head), the 
middle section (body) is the space for activities. In contrast, the lower part becomes under the building or area under construction [6]. The space organization in the Deli Malay house has similarities with the traditional house space organization in general.

\section{Methodology}

The adopted method in this research is a qualitative method descriptive. This research is intended to understand the results of the study vernacularism in traditional Malay houses based on technical aspects by focusing on structural systems that include construction and materials to determine the characteristics of the existing vernacular architecture in a traditional Malay house.

This research activity is carried out by examining related matters with vernacular architecture regarding its forming aspects, namely technical aspects through literature study, observation, and field documentation.

\section{Results and Discussion}

The traditional Malay Deli house is the object of this research located on Jalan Tahi Bonar Simatupang, Lalang, Kec. Medan Sunngal is a family heritage that has been settled since 1950 with a Malay ethnic background or has a relative relationship with Deli's sultan, known as a noble family (Figure 2).

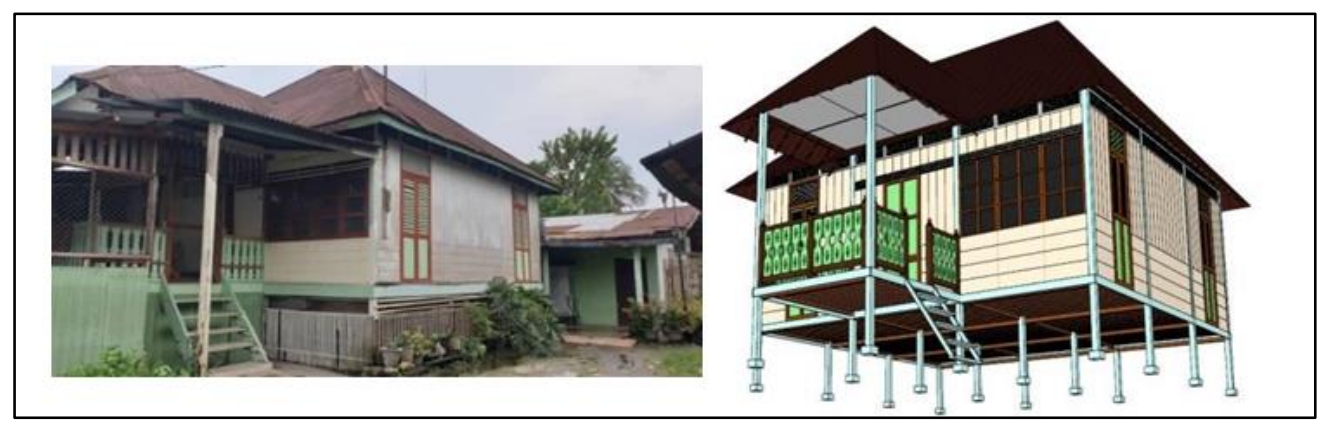

Figure 2 Traditional malay deli house

The vernacular architecture in this traditional house is not only influenced by socio-cultural aspects but also influenced by the technical aspect. The influence of the technical aspects of this house seen in its elements or joints has a connection with the tradition in the process of building traditional houses in the form of a legacy passed down from older generation to younger generation in the form of construction techniques or structural elements that represent local wisdom in the area.

\subsection{Substructure}

This building's lower structure located above the ground level consists of a foundation, foundation piles, outer joist and frame. Generally, using a straight notch connection, which then locked with nails or bolts. the lower structure used as a place to raise livestock (Figure 3). 


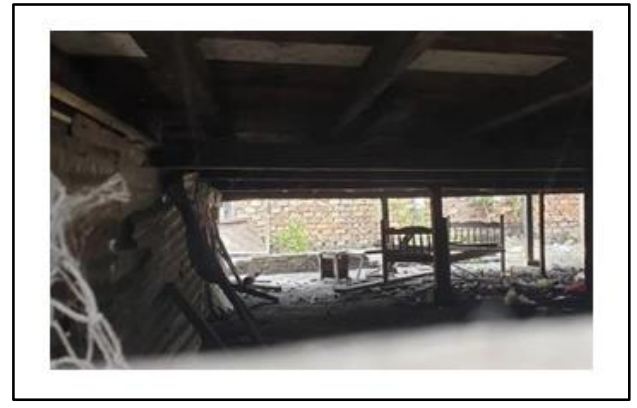

Figure 3 Substructure for livestock

\subsubsection{Foundation}

The foundation used in this building is the mortar foundation or 'umpak' placed on the ground surface with dimensions of mortar footing or about $20 \times 20 \mathrm{~cm}$, whereas the pole's dimensions are $12 \times 12 \mathrm{~cm}$ with a height of approx 1.10 meters (Figure 4). In its installation, the foundation is tied with frame board 'selempang' to make it stable. The foundations for this traditional house are 18 pieces made of sea resin wood. The connection between the foundations minimizes damage because it can dampen and reduce vibrations from the ground [20].

The mast in the lower structure consists of 14 main posts and four support poles connected by outer joist or 'samge' around the house or central pillar. Outer joist used as a connection cover on the house's floor structure wherein other Malay houses it only functions as a place to tie the foundation piles (Figure 5). The outer joist dimension is $12 \mathrm{~cm}$. At its installation, the outer joist nailed to the foundation piles by placing a bearing between them.

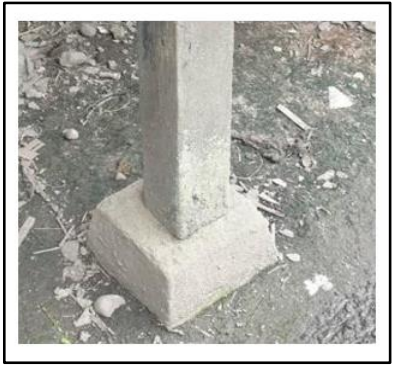

Figure 4 Mortar foundation

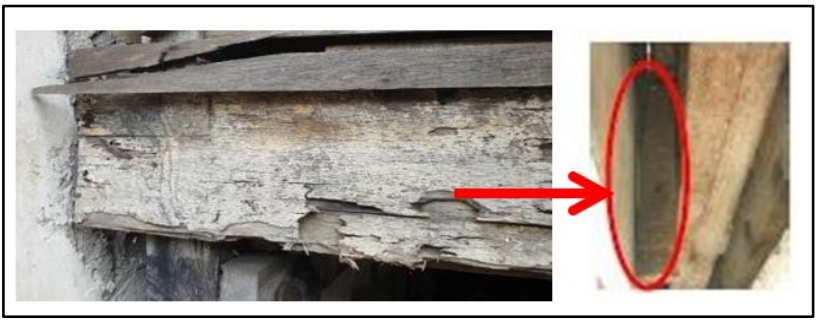

Figure 5 Outer joist as frame

\subsection{Bottom Side Superstructure}

This traditional house's central structure used as a place to carry out activities by its residents. The middle structure includes the kip (bearings), girders, columns, wall frames, wallboards, top and down, door and window frames, and stairs all done inside one level with a height of about $2.80 \mathrm{~m}$. As with the lower structure, the centre structure's joints are straight notch joints for the structural elements and the tongue joints for the wooden planks.

\subsubsection{Floor}

Loads that are above the floor surface supported by the floor joists or 'gelagar' and transmitted to the kip (bearing) located opposite and flanked by support beams and eventually distributed 
evenly on each foundation (Figure 6). The connection used on this floor structure is a half-lap joint or 'takikan lurus' connection, which is nailed with nails to make it more rigid (Figure 7).

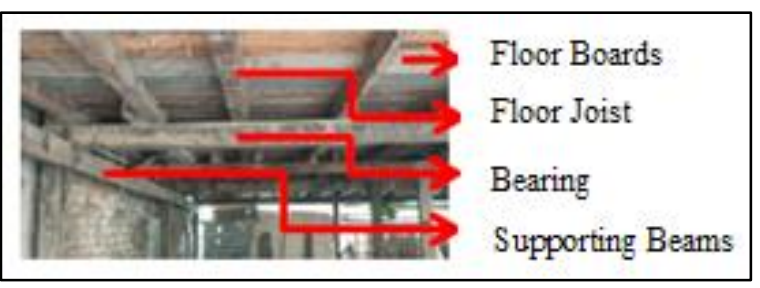

Figure 6 Floor structure

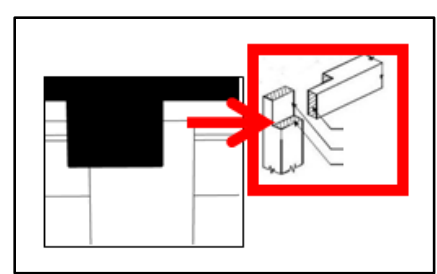

Figure 7 Half-lap joint

The kip dimensions are $10 \mathrm{~cm}$ in the opposite direction to the girder and are secured by poles using a half-lap joint (Figure 8). Meanwhile, the support beam serves as the seat for the kip and surrounds the house in one direction (Figure 9).

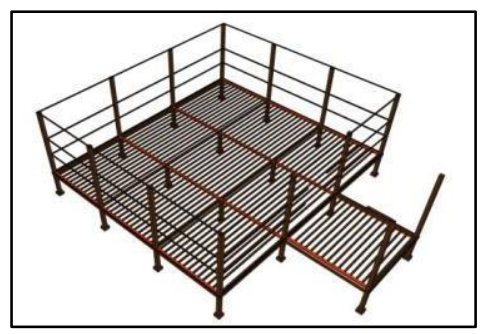

Figure 8 Kip (bearing) and floor joists

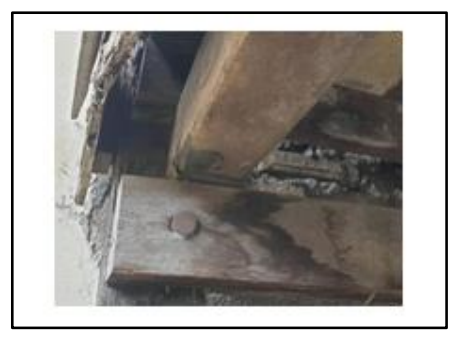

Figure 9 Supported beams

This building's total floor surface area is about $60 \mathrm{~m} 2$ with dimensions of $12 \mathrm{~cm}$, which consists of $56 \mathrm{~m} 2$ of the entire space in the building and $4.6 \mathrm{~m} 2$ for the terrace floor (Figure 10). The floor covering used on the floor surface is wood planks derived from meranti wood, using the tongue and hole board system so that the arrangement is tight and then nailed above the girder at the end of the wooden board to lock the arrangement (Figure 11).

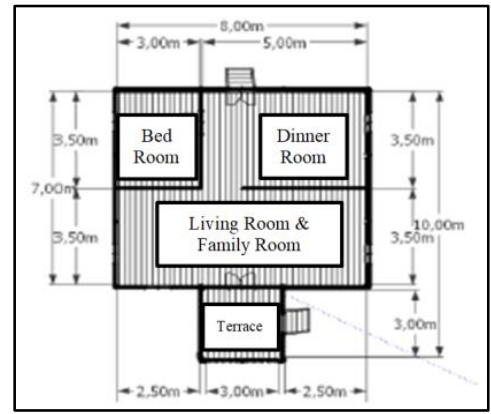

Figure 10 Cover Surface Area

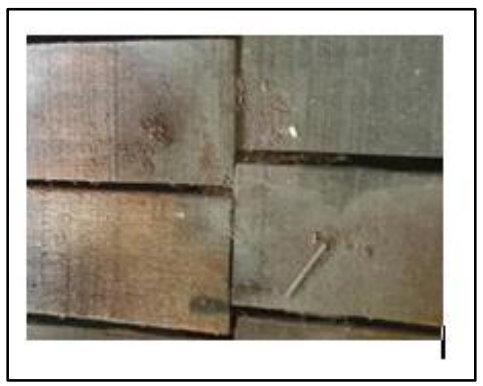

Figure 11 Floorboard Joint

\subsubsection{Column}

The column results from an extension of the foundation pile and has the same material as the foundation. structural column consists of 18 pieces, each measuring $12 \times 12 \mathrm{~cm}$. In contrast, the support column consists of 4 pieces having a size of $10 \times 10 \mathrm{~cm}$ (Figure 12). The column itself has a half-lap connection, especially in the joint area between poles and post caps, top and bottom vines with support types joints. 


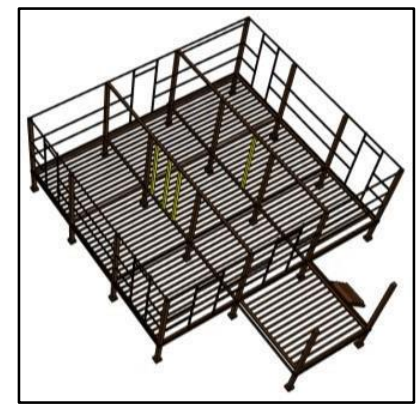

Figure 12 Main Column and support column

\subsubsection{Wall}

The walls of this traditional house have a height of about $2.80 \mathrm{~m}$. This wall consists of wall frames, boards, sheets, and openings such as frames and windows whose material comes from marine resin (Figure 13). Previously, the wall frame was made in advance, formed using wood with about $6 \times 8 \mathrm{~cm}$. Wall frames are adapted to the needs of openings in the form of windows and doors.

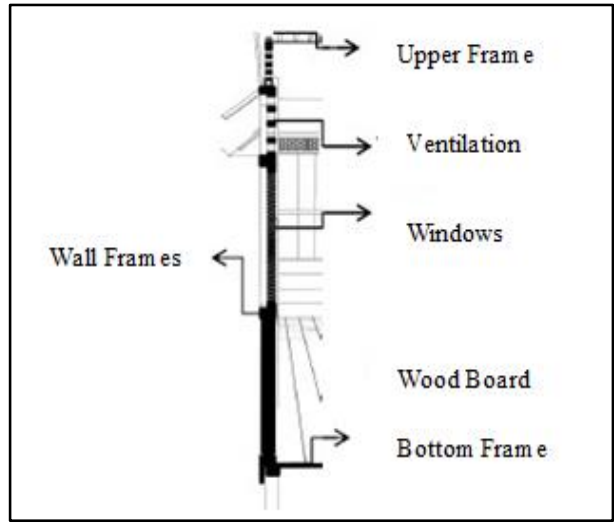

Figure 13 Wall Structure

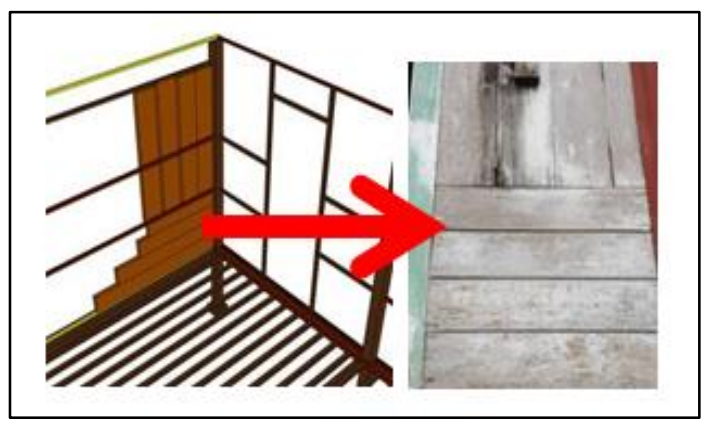

Figure 14 Wall Boards

The wooden planks are positioned between the top and bottom joints of the frame to attach the wallboards (Figure 14). In this traditional house, it is used only as a base for the stand wooden planks because half of the wall is a wooden plank installed horizontally and directly above it is placed the board vertically but flanked by vents. In contrast, the connection used between the boards is the tongue connection and holes, which are then nailed into the frame to lock in the arrangement of the board.

\subsubsection{Openings (Windows and Doors)}

The dimensions of the windows and doors are about one meter with a height of 2.10 meters while the upper side of the wall is filld by a vent with a height about $50 \mathrm{~cm}$ and $80 \mathrm{~cm}$ from the top of the opening so that the air exchange in the space can be done well (Figure $15 \& 16$ ). Ventilation is also used as a homeowner's natural lighting when the window is closed (Figure 17). 


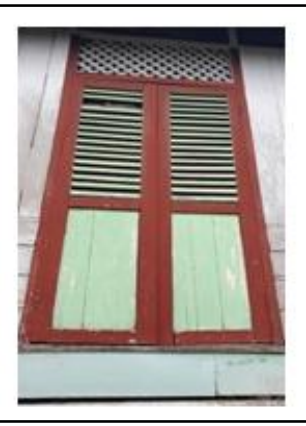

Figure 15 Windows

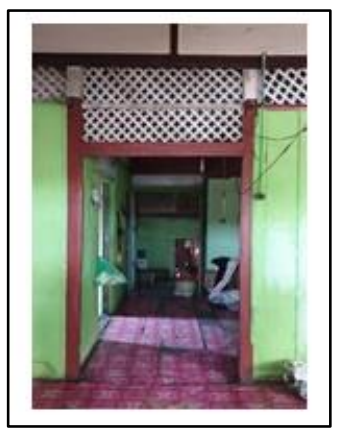

Figure 16 Door

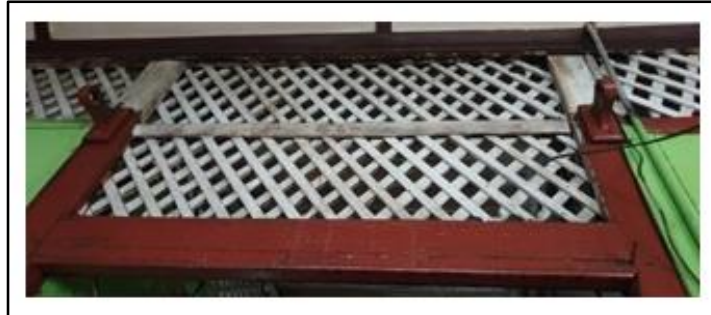

Figure 17 Ventilation

\subsubsection{Staris}

The wood ladder or stairs in a traditional house is a combination of the lower structure and the middle structure (Figure 18). With the number of five steps, and $30 \mathrm{~cm}$ dimensions, in its installation using a motise and tenon joint system between the steps and the frame (Figure 19).

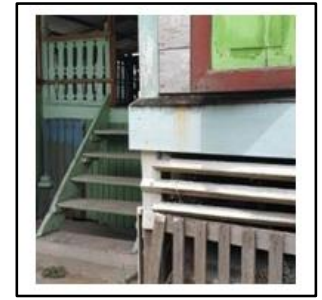

Figure 18 Stairs

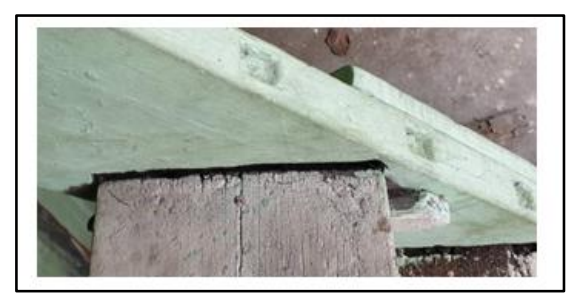

Figure 19 Mortise and Tenon Joint

\subsection{Upper Side Superstructure}

The upper side superstructure is used to place the roof truss, which the homeowner chooses to leave the space empty (Figure 20). The upper structure in this traditional house includes the roof shaped like a pyramid and closed pole, which is the top stiffener of the central pillar. The roof itself is a roof truss and roof cover. The material used is wood for the structure with joint support, except for the roof cover, which is a type of old zinc material used to be palm fibre.

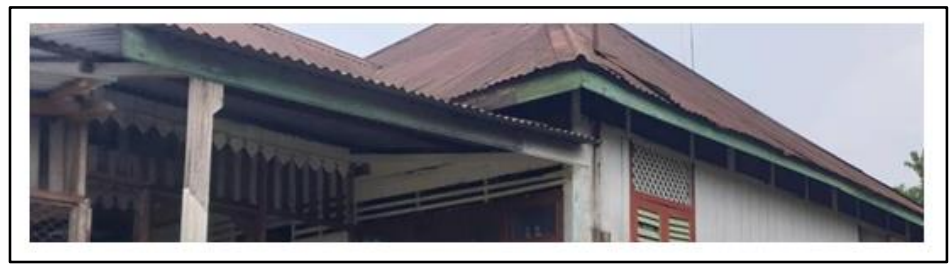

Figure 20 Upper Side Superstructure

The barrier between the upper structure and the lower structure of this building is the ceiling which is the arrangement of the upper truss or 'gelagar atas' then put a sheet of wood on it (Figure 21). 


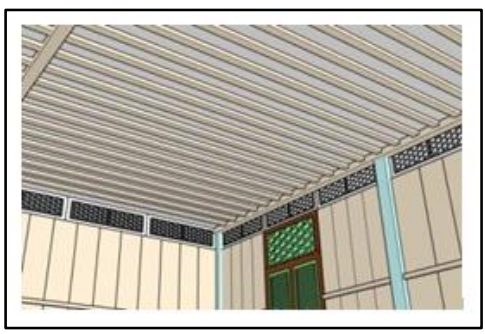

Figure 21 Ceiling

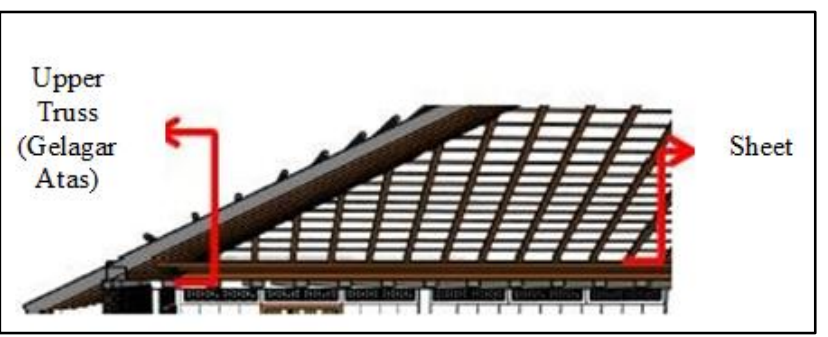

Figure 22 Ceiling Structure

The pole cap is placed according to the direction of the kip or bearing. Its location is under the upper truss, which is useful as support or cover of the mainmast (Figure 22). The connection between the post and the beam is itself a straight notch close. The pole on this traditional Malay Deli house can be found in simple houses, usually referred to as ring beams.

\subsubsection{Roof Truss}

Roof truss applies a simple truss system that is placed on the beam ring (Figure 23). These horses consist of rafters and battens. Above it, a ridge beam with a dimension of $4 \mathrm{~cm}$ is placed to lock the roof frame's connection, and a locking beam fastens the ends of the frame (Figure 24).

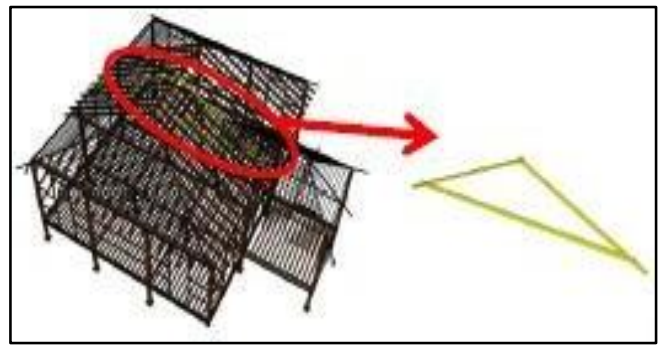

Figure 23 Roof Truss

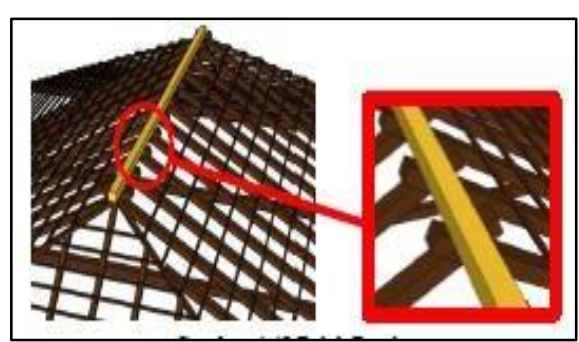

Figure 24 Ridge Beam

\subsubsection{Roof Cover}

The type of roof covering on this building is zinc. However, according to the source of this traditional house roof cover used to be palm fibre, this seen in the roof truss structure where the frame shape adjusted with cords as the roofing material. For laying the general ornament located around the roof.

\subsection{The Characteristic Structure System Of The Malay Deli Traditional House}

\subsubsection{Roof}

The roof of the traditional Malay Deli house is a pyramid shape simple without ornament, especially in structural ornamentation building. This roof is formed from the extension of the rafters' interlocking joints, which are both secured with nails and create a support for the ridge beam using a simple truss structural system consisting of rafters and battens as a holder of thatch. This arrangement is a characteristic of the traditional Malay house Deli (Figure 25). 


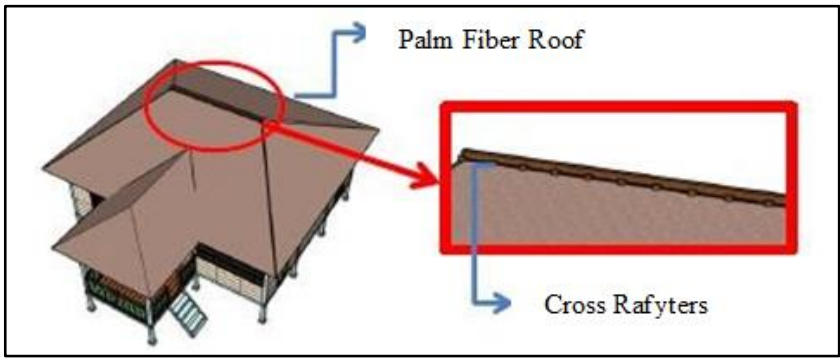

Figure 25 Roof Characteristic

\subsubsection{Ceiling}

The ceiling has a motif formed by the above arrangement, which is lined by wood surface/sheet, this sky forms. The ceiling also acts as a structure, especially as a space under the roof. The former owner make this place a place to put things (Figure 26).

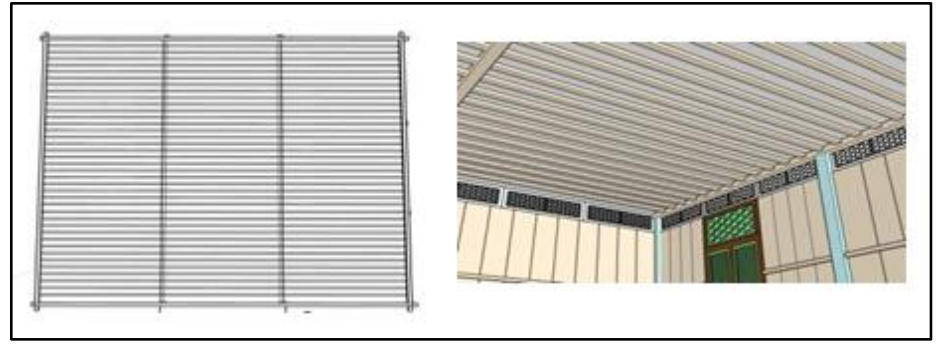

Figure 26 Ceiling Characteristic

\subsubsection{Wall}

The frame wood supports the traditional Malay Deli house walls as a support for openings, vents, and wooden boards. Middle structure the traditional Malay Deli house is a marker of the house, such as the openings that extend upwards and the surrounding ventilation throughout the house.

The wooden frame also affects the shape of the board arrangement wood, namely vertical or horizontal. In the traditional Malay Deli house, the middle of the vertical wooden plank is supported by a wooden frame not to bend. In contrast, for horizontal wood planks, it is only used as a backrest of these wooden planks (Figure 27).

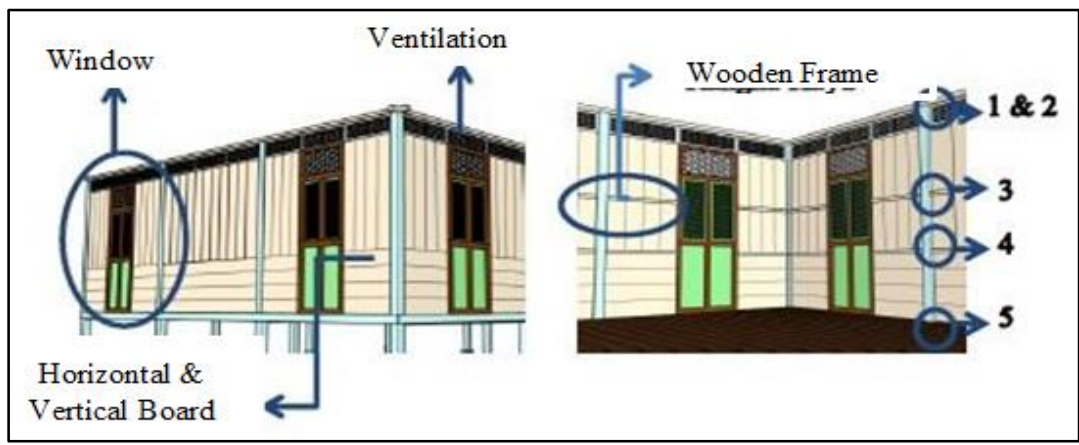

Figure 27 Wall Characteristic 


\subsubsection{Floor}

The floor structure elements follow which support beam system the beams support each other with the addition of bearings for filling in the gaps between structures. Due to the system's interactive nature, the floor structure can be seen as obvious if viewed from outside the house. Hence a cover in the form of a outer joist or 'samge' is used, which covers the structure or pile straightener. The outer joist can also protect the structure out of the rain. The size is large enough to cover the structure floor, outer joist is part of the typical Malay Deli traditional house (Figure 28).

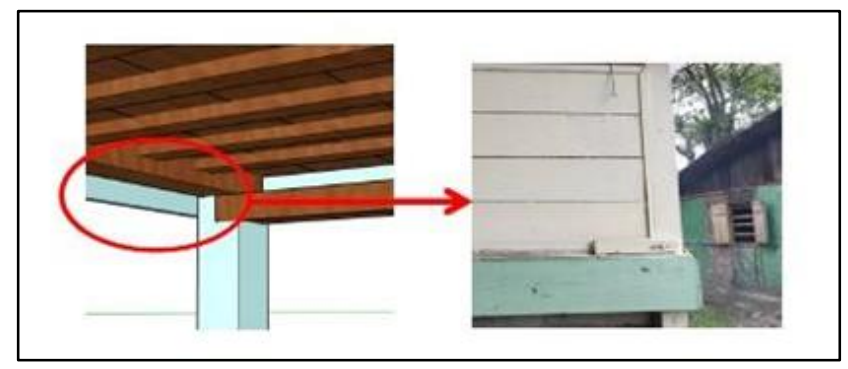

Figure 28 Floor Characteristic

\subsubsection{Stairs}

The ladder is used as a tool to enter the house. The stairs in this traditional house are made of wooden planks with shapes simple without the use of railings due to the height between ground levels. the floor height is $1.10 \mathrm{~m}$ and arranged with five wooden planks each is attached to the ladder frame using a mortise and tenon connection (Figure 29).

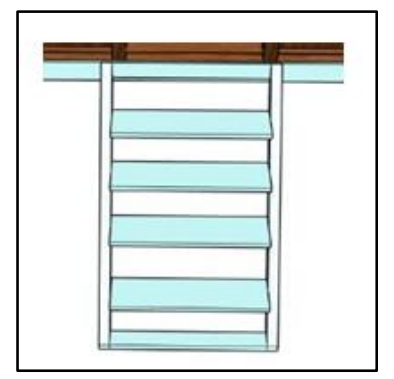

Figure 29 Stairs Characteristic

Railing on the terrace is arranged by utilizing the wooden frame's position on the walls numbered 4 and 5, which were then formed around the terrace of the house and placed a boundary in the form of a patterned wooden board (Figure 30). Likewise, board carving wood that is above the railing as a place for the wooden frame to be placed one and two (Figure 31). 


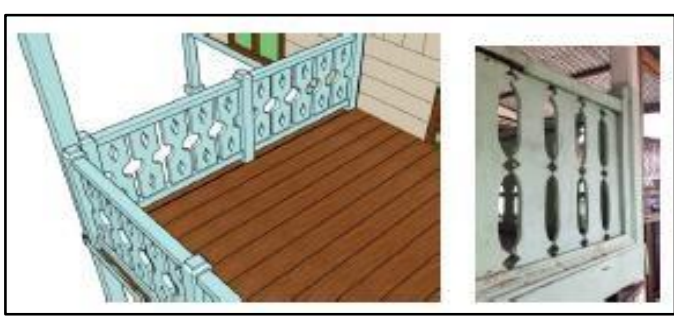

Figure 30 Railing Characteristic

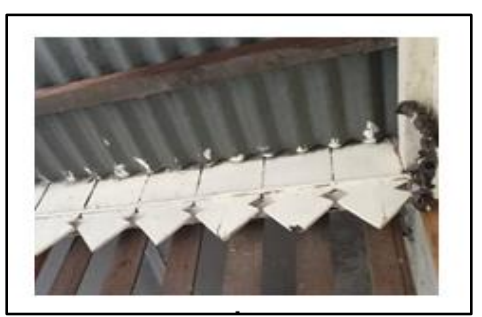

Figure 31 An ornament on the upperside of the ceiling

\section{Conclusions}

The Melayu Deli house is a traditional house with a structural system that application can be found in a simple Malay house generally and an ordinary house. But what distinguishes it is uniqueness in the form of characteristics, especially in the structural system that forms the traditional house. The characteristic of the vernacular architecture of the traditional Malay Deli7ti house formed of the structural system, which seen from the elements that make up the structure, these structural elements emphasize the shape of the house traditional Malay Deli so that its characteristics are seen. In research development in the future, vernacular architecture in traditional houses, especially Melayu Deli, in terms of other aspects, especially the non- technical aspects of how these aspects can form the characteristics of the architecture vernacular Deli Malay traditional house.

\section{REFERENCES}

[1] Antariksa, "Permaslahan Konservasi Dalam Arsitektur dan Perkotaan," Jurnal PlanNIT, vol. 15 , no. $1,2005$.

[2] R. Piutanti, "Pemaknaan Kembali Kearifan Lokal Dalam Arsitektur (Keterkaitan Manusia Budaya dan Alam Nusantara)," Seminar Nasional "Finding The fifth Element. After Water, Earth, Wind, and Fire" Local Wisdom and Cultural Sustainability, vol. 6, no. 1, pp. 13-21, 2015.

[3] Heryanti and N. Abdul, "Kearifan Lokal Pada Arsitektur Vernakular Gorontalo: Tinjauan Pada Aspek Budaya dan Nilai-nilai Islam," El Harakah, vol. 16, no. 2, pp. 151-173, 2014.

[4] M. Turan, Vernacular architecture : paradigms of environmental response. Brookfield: Aldershot, 1990.

[5] Z. Syaifuddin, "Performansi Teknologi Sebagai Pembentuk Rupa dan Ruang Arsitektur," Jurnal Rekayasa Perencanaan, vol. 12, pp. 105-116, 2005.

[6] M. Handayani, M. Nawawiy Loebis, N. Ginting, and H. Tamiami, "Karakter Spasial Hunian Vernakular Melayu Deli," EE Conference Series, vol. 2, no. 1, pp. 107-114, 2019.

[7] C. Nursaniah, "Konsep Kearifan Lokal dari Konstruksi Rumah Vernakular di Pesisir Barat 
Aceh untuk Perancangan Arsitektur Modern Studi Kasus: Wilayah Das Krueng Tripa, Kabupaten Nagan Raya," Tesa Arsitektur, vol. 14, no. 2, pp. 55-63, 2017.

[8] Victor Papanek, The Green Imperative: Ecology and Ethics in Design and Architecture. London: Thomas and Hudson, 2013.

[9] A. Rapoport, House Form and Culture. New Jersey: Pren tice-Hall, 1969.

[10] P. Oliver, Dwellings: the vernacular house world wide. London: Phaidon Press, 2003.

[11] N. Davies and J. Erkki, Dictionary of architecture and building construction. London: Architectural Press, 2008.

[12] W. Hary Susilo, "Budaya Masyarakat Dalam Membangun Rumah Vernakular Di Pesisir Pantai," Maysrakat, Kebudayaan dan Politik, vol. 27, no. 1, pp. 55-64, 2014.

[13] A. A. Herman Balo, "Arsitektur Vernakular Tolaki," Seminar Nasional Teknologi Terapan Berbasu Kearifan Lokal, vol. 1, no. 1, 2019.

[14] I. Mentayani, Ikaputri, and P. Muthia, "Menggali Makna Arsitektur Vernakular: Ranah, Unsur, dan Aspek-aspek Vernakularitas," Prosiding Temu Ilmiah IPLBI, vol. 1, no. 2, pp. 109-116, 2017.

[15] Michael Masner, "Is There A Modern Vernacular," in Companion to contemporary architectural thought. London dan New York: Routledge, 1993, pp. 198-201.

[16] D. L. Schodek, Struktur. Indonesia: Erlangga, 1999.

[17] P. Luthan, I. Nasution, and K. Jeumpa, "Struktur Bangunan Tradisional Mandailing," Jurnal Saintika, vol. 14, no. 2, pp. 141-149, 2014.

[18] Hendrikus Trivaldo, Zairin Zain, and M. Nurhamsyah, "Identifikasi Sistem Struktur Dan Konstruksi Rumah Melayu Di Pontianak," Jurusan Arsitektur Universitas Tanjung Pura, Tanjung Pura, 2019.

[19] H. Frick, Pola struktural dan teknik bangunan di Indonesia: suatu pendekatan arsitektur Indonesia melalui pattern language secara konstruktif dengan contoh arsitektur Jawa Tengah. Yogyakarta: Kansius, 1997.

[20] W. Ibrahim, "Arsitektur Tradisional Kenali Salah Satu Kearifan Lokal Daerah Lampung," Juranl Reakayasa, vol. 15, no. 1, pp. 55-66, 2011. 